Johannsen, W. Does hybridisation increase fluctuating variability. Report of the third international Conference 1906 on Genetics. London 1907.

- Elemente der exakten Erblichkeitslehre. Jena Igog.

Lock, Robert H. Recent progress in the study of variation, heredity and evolution. London 1907.

Pearson, Karl. The grammar of science. II. Aufl. London Igoo.

- Mathematical contributions to the theory of evolution:

Regression, Heredity and Panmixia. Philosophical transactions of the Royal Society of London 187 A. 1896.

Genetic Selection. Ebenda 192 A. I 899.

On the inheritance of characters not capable of exact inconcerement. Ebenda I95 A. 1899.

On the principle of homotyposis and its relations to heredity, to the variability of the individual and that of the race. Ebenda 197 A. 1900.

On the influence of natural selection on the variability and correlations of agens. Ebenda 200 A. 1902.

On a generalised theory of alternative inheritance with special reference to Mendels laws. Ebenda 203. I9O4.

- On the law of an ancestral heredity. Proc. Royal Society of London 62. 1898.

- On the law of reversion. Ebenda 66. 1900.

- On the law of inheritance in man. Biometrica 2. 1903.

- A first study of the statistics of pulmonary tuberculosis. London 1907.

- On a criticism which may serve to test various theories of inheritance. Zeitschr. f. Anthrop. und f. Morphol. 7 1904. S. 524.

Punnet, R. C. Mendelism in relation to disease. Proceedings of the royal Society of Medicin I. 5. 3. 1908.

Thomson, Arthur. Heredity. London 1908.

Weinberg, Wilhelm. Pathologische Vererbung und genealogische Statistik. Deutsches Archiv f. klin. Medicin 78. I903.

— Die familiäre Belastung der Tuberkulösen usw. Beiträge zur Klinik der Tuberkulose VII. I907.

- Aufgabe und Methode der Familienstatistik bei medizinisch-biologischen Problemen. Zeitschrift für sociale Medicin I. 1907.

- Uber den Nachweis der Vererbung beim Menschen. Jahreshefte des Vereins für vaterländische Naturkunde in Württemberg. 1908.

- Die Anlage zur Mehrlingsgeburt beim Menschen und ihre Vererbung. Archiv für Rassen. und Gesellschaftsbiologie VI. 1909. Heft 3-5.

Yule, G. Uduy. On the theory of correlation. Journal of the Royal Statistical Society of London 60.1897.

- Mendels laws and their probable relations to interracial heredity. The new phytologist 2. I902.

- On the theory of quantitative compound characters on the basis of Mendel laws. Report of the 3. international conference 1906 on genetics. London 1907.

\title{
Corrigenda zum allgemeinen Teil, Bd. I dieser Zeitschrift.
}

Seite 450 Zeile 10 und $\mathrm{I} 2$ von oben lies statt Tnm : D.

\begin{tabular}{|c|c|c|}
\hline & I9 & " Tnm : R. \\
\hline Seite 457 & 2 & \# unten fällt weg : genau. \\
\hline Seite 458 & ." & $\begin{array}{l}\text { "oben schalte ein nach Umstände: innerhalb der } \\
\text { angegebenen Grenzen. }\end{array}$ \\
\hline
\end{tabular}

